\section{Advisory Committee for Scientific and Technical Information}

Tre Secretary of State for Education and Science has appointed the following to the Advisory Committee for Scientific and Technical Information, the setting up of which he announced in the House of Commons on April 27 (Nature, 206, 665, 1965; 207, 234, 1965): Sir James Cook, Vice-Chancellor, University of Exeter (chairman); Dr. N. F. Astbury, director, British Ceramic Research Association; Dr. J. W. Barrett, research director, Monsanto Chemicals, Ltd.; Prof. J. D. Bernal, professor of physics and of erystallography, Birkbeck College, University of London; Dr. G. M. Dyson, consultant; Prof. S. Gill, professor of computing science, Imperial College of Science and Technology, London; Prof. S. P. Hutton, head of Mechanical Engineering Department, University College of South Wales and Monmouthshire, Cardiff; Dr. R. M. Lodge, research manager, Imperial Chemical Industries Fabrics, Ltd.; Prof. G. A. Smart, professor of medicine, University of Newcastle upon Tyne; Mr. B. C. Vickery, librarian, Manchester College of Science and Technology.

\section{Mond Chemical Products}

Tre name 'Mond' has become so closely associated with nickel as to be practically synonymous. We think of Mond nickel in terms of various types of nickel steel production, nickel crucibles, tubes, modern coinage, 'nichrome' electric resistance furnaces and heaters, etc., but the diverse applications of this metal in the form of oxides and salts are perhaps not so generally appreciated and do not necessarily recall the name 'Mond' in this particular context. If such omission has indeed existed, it has now been well and truly repaired by the recent issue of a booklet entitled Mond Chemical Products (Pp. 10. London: International Nickel Co. (Mond), Ltd., 1965). Apart from nickel oxide and its salts, the 'Mond' range of compounds summarized in this publication includes cobalt oxides and salts, selenium compounds and tellurium. In an accompanying Press reloase note it is stated that: "Mond chemicals ... are used in one form or another in such differing places as the kitchen and the paint pot, the machine shop and the farm, the plating shop and the pottery". This great range of uses obviously implies a common factor, namely, a high degree of uniformity and purity in the several chemicals themselves. In this booklet each of the commonly available compounds of nickel, cobalt, selenium, and the tellurium product, are described under the headings: product and formula, approximate content of nickel, cobalt, etc., appearance (form and colour), trade in which used, and purpose of such use; it is in the last category that the wide use of these chemicals is realized. Nickel compounds find uses as alloy additions, active materials for storage batteries, catalysts, colours, fungicides, plating solutions, etc.; cobalt oxides and salts are used as catalysts, colours, for correcting cobalt deficiency in farming, driers, moisture indicators and mordants ; selenium compounds are used as colours, catalysts, decolorizers, electrical rectifiers, oxidizing agents, stainless steel, etc., tellurium finds its chief use in the metal industries as an addition element for machinability or, in the case of cast iron, as a carbide stabilizer. A short list of publications dealing with the use of these 'Mond' chemical products, and a list covering world-wide distributors of them, complete the useful data to be found in this booklet.

\section{The Albright and Wilson Group}

THe name of Albright and Wilson has long been associated with the manufacture and marketing of phosphates on a world-wide scale, but in the past few years there have been some major changes in product range, brought about partly by the absorption of other manufacturing companies concerned with both fine and heavy chemicals. To-day, the Albright and Wilson Group embraces more than thirty-five companies operating predominantly in the chemical field; it manufactures in eleven countries, employs about 11,000 personnel, commands assets now exceeding $£ 45$ million, and has a sales turnover of more than $£ 60$ million. To bring the public up to date with the present and expanding activities of the Group, there has recently been published a small illustrated brochure which provides a succinct account of its contemporary activities (Pp. 28. London: Albright and Wilson, Ltd., 1965). Detergent and shampoo raw materials have, according to this booklet, been the greatest single factor in the growth of Albright and Wilson during the past fifteen years, because heavy-duty powder detergents contain at least a third by weight of sodium tripolyphosphate as an essential water-softening and dirt-disposal agent. Marchon Products, Ltd., joined the Group in 1955 and this led to further contributions to detergents, notably surface-active agents such as alkyl aryl sulphonates, fatty alcohol sulphates, and other specialized ancillaries such as hydrotropes and foam stabilizers. The Group is one of the leading world suppliers of shampoo raw materials for hair-washing, car and carpet shampoos. In the field of fertilizers, insecticides and herbicides, the Group is strongly established; a plant at Port Maitland, Ontario, has an output of 275,000 tons of single and triple superphosphate, phosphatic solutions and feed-grade dicalcium phosphate. Thiophosphates, long made by Albright and Wilson for insecticides, continue in demand, but with the recent addition to the Group of Stafford Allen and Sons, Ltd., the range is now supplemented with the important pyrethrum and derris extracts. Sodium chlorate continues as a weed killer, but the tendency is now towards the use of organic herbicides such as ammonium sulphamate; for fungicides and bactericides, organo-tin chemicals manufactured by the Group (for example, tributyl tin oxide) are of increasing importance. Another important field concerns flavours and fruit extracts, involving production of essences, essential oils, juice compounds, and powders; spices are included. Fruit juices, extracts and concentrates are produced by the Group in eight countries, the most important being derived from lemons and oranges. Other interests lie in metal-finishing chemicals and processes, manufacture of perfumery and cosmetic products, pharmaceutical products, plastics and paint chemicals, silicones, sodium chlorate and paper products. The brochure concludes with brief notes on other products of the Group, on sales and marketing organizations of the member companies, technical service, research and development, and on the work of its engineering departments responsible for design and construction of most of the new plants and factories required.

\section{City of Gloucester Museums}

The report of the City of Gloucester Museums for the year ended March 31, 1964, issued in an attractive format, gives some idea of the extremely munificent bequest received under the will of the late Mr. Samuel Stanley Marling (Pp. $16+4$ plates. Gloucester: The Museums, 1965). It comprised eighteenth-century furniture, English domestic silver, Bristol and Nailsea glass, period barometers, clocks and watches, early treen, English gold coins, and eleven oil-paintings attributed to Richard Wilson (1713-82). Outstanding objects include an ivory. cased stick barometer by Daniel Quare (1648-1724), a month long-case clock by Christopher Pinchbeck (1670 1732 ), and an exceptionally fine silver-gilt inkstand in the form of a celestial globe, made by John Robbins in 1792 . A token exhibition of the bequest was staged in 1963, but the remainder must await the building of two additional galleries as extensions to the City Museum. These will be constructed over the present single-storey section of the Brunswick Road buildings. Six further cabinets have been constructed to house the herbarium, and the Upton Collection of land and freshwater molluses has been 